B. ЧЕРНЫШЕВ, Анне ОРАВ, Сильвия РАНГ, Кай КУНННГАС, А. ЭРМ, Х. РАНГ

\title{
ИЗУЧЕНИЕ ПРОДУКТОВ ДЕГИДРОХЛОРИРОВАНИЯ ТЕЛОМЕРОВ
}

V. TSERNOSEV, Anne ORAV, Silvia RANG, Kai KUNINGAS, A. ERM, H. RANG. TELOMEERIDE DEHUDROKLOORIMISE PRODUKTID

V. CHERNYSHEV, Anne ORAV, Silvia RANG, Kai KUNINGAS, A. ERM, H. RANG. DEHYDROCHLORINATION PRODUCTS OF TELOMERS

Определение состава образующихся продуктов присоединения алкенов к ненасыщенным хлоридам - серьезная аналитическая проблема. Одним из способов определения состава продуктов служит дегидрохлорирование теломера, в результате которого образуются диеновые соединения. Строение последних может дать первоначальную информацию о составе теломера. Депидрохлорирование теломеров проводили по методике [1]. С целью идентификации синтезированные диены очищали методом препаративной ГЖХ. Препаративное разделение диенов проводили на хроматографе «Выру-Хром-П2» при температуре термостата $140^{\circ} \mathrm{C}$ и испарителя $200^{\circ}$ (газ-носитель - гелий, детектор катализатор). Использовалась колонка диаметром 10 мм и длиной 2 м с твердой фазой хроматона N-AW, пропитанного $10 \%$-ным этиленгликольполиадипинатом (от веса твердого носителя). Физико-химические показатели диеновых соединений приведены в табл. 1. Идентификация выделенных диенов по спектрам ${ }^{-13} \mathrm{C}$-яМР приведена в [2].

Кроме того на сквалане при различных температурах были изучены индексы удерживания полученных диенов. Состав полученных продуктов определяли на хроматографе «Хром-2» с пламенно-ионизационным детектором (газ-носитель - гелий). Давление газа-носителя

Таблица 1

Физико-химические показатели полученных диенов

\begin{tabular}{|c|c|c|c|}
\hline Название диенового соединения & $d_{4}^{20}$ & $n_{D}^{20}$ & $\begin{array}{l}\text { Чнстота по } \\
\text { ГЖХ, \% }\end{array}$ \\
\hline $\begin{array}{l}\text { 2,4-Диметил-1,5(Е)-гептадиен } \\
2,4-\text { Диметил-2,5(Е)-гептадиен } \\
\text { 2,6-Диметил-1,5-гептадиен } \\
\text { 2,6-Диметил-2,5-гептадиен } \\
\text { 2,3,4-Триметил-1,5(Е)-гептадиен } \\
\text { 2,3,4-Триметил-2,5(Е)-гептадиен } \\
\text { 2,3,6-Триметил-1,5-гептадиен } \\
\text { 2,3,6-Триметил-2,5-гептадиен } \\
\text { 4-Метил-2(Е),6(E)-нонадиен } \\
\text { 4-Метил-2(Е),6(Z)-нонадиен } \\
\text { 4-Метил-2(Е),5(Е)-нонадиен } \\
\text { 4-Метил-2(Е),5(Z)-нонадиен } \\
\text { 2,3,3,4-Тетраметил-1,5(Е)-гептадиен } \\
\text { 2,3,3,6-Тетраметил-1,5-гептадиен }\end{array}$ & $\begin{array}{l}0,7448 \\
0,7462 \\
0,7476 \\
0,7496 \\
0,7721 \\
0,7789 \\
0,7710 \\
0,7777 \\
0,7721 \\
0,7700 \\
0,7681 \\
0,7651 \\
0,7969 \\
0,7859\end{array}$ & $\begin{array}{l}1,4325 \\
1,4381 \\
1,4345 \\
1,4398 \\
1,4400 \\
1,4535 \\
1,4470 \\
1,4585 \\
1,4501 \\
1,4481 \\
1,4461 \\
1,4448 \\
1,4525 \\
1,4520\end{array}$ & $\begin{array}{l}98,6 \\
98,5 \\
99,3 \\
98,9 \\
99,1 \\
99,9 \\
99,1 \\
99,0 \\
98,3 \\
96,3 \\
96,7 \\
95,6 \\
99,3 \\
99,1\end{array}$ \\
\hline
\end{tabular}


Индексы удерживания диенов на сквалане

\begin{tabular}{|c|c|c|c|c|c|}
\hline \multirow{2}{*}{ Диеновый углеводород } & \multicolumn{4}{|c|}{ Температура, ${ }^{\circ} \mathrm{C}$} & \multirow{2}{*}{$10\left(\delta I /{ }^{\circ} \mathrm{C}\right)$} \\
\hline & 80 & 100 & 110 & 120 & \\
\hline 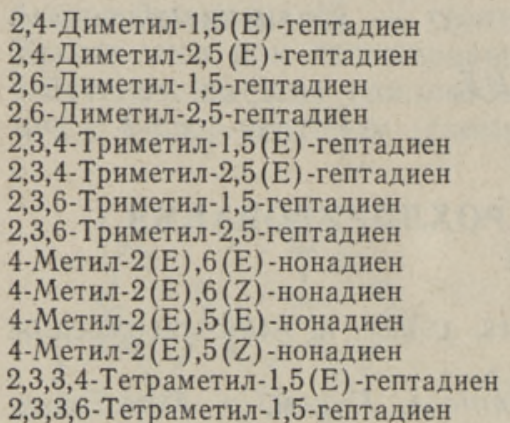 & $\begin{array}{l}814,5 \\
829,8 \\
863,5 \\
894,8 \\
885,4 \\
942,6 \\
917,2 \\
983,5 \\
925,6 \\
936,1 \\
931,7 \\
941,5 \\
984,0 \\
986,5\end{array}$ & $\begin{array}{l}815,4 \\
828,5 \\
862,1 \\
894,3 \\
887,5 \\
942,3 \\
917,8 \\
982,5 \\
925,4 \\
937,2 \\
931,5 \\
942,0 \\
987,0 \\
989,1\end{array}$ & $\begin{array}{l}815,6 \\
828,2 \\
862,2 \\
894,2 \\
888,8 \\
941,8 \\
918,5 \\
982,5 \\
925,8 \\
937,5 \\
931,0 \\
942,4 \\
988,6 \\
990,2\end{array}$ & $\begin{array}{l}816,2 \\
827,1 \\
862,3 \\
893,8 \\
889,3 \\
941,5 \\
918,5 \\
982,7 \\
925,3 \\
937,6 \\
930,2 \\
942,4 \\
990,4 \\
991,4\end{array}$ & $\begin{array}{l}+0,42 \\
-0,68 \\
-0,17 \\
-0,25 \\
+0,97 \\
-0,32 \\
+0,33 \\
-0,10 \\
-0,07 \\
+0,32 \\
-0,47 \\
+0,22 \\
+1,60 \\
+1,20\end{array}$ \\
\hline
\end{tabular}

$1,5-1,7 \kappa 2 / \mathrm{cm}^{2}$. Средняя линейная скорость газа-носителя $0,3 \mathrm{~cm}^{3} / \mathrm{muн}$. Скорость ленты самописца 360 мм/ч. Использовалась колонка из нержавеющей стали длиной 50 м и внутренним диаметром 0,25 мм, покрытая скваланом и с числом теоретических тарелок по пику н-декана 80000 . Индексы удерживания определены при температурах 80, 100, 110 и $120^{\circ}$ (табл. 2). Зависимость индексов удерживания от температуры колонки в заданном интервале температур линейная. Индексы удерживания вообще мало зависят от температуры (индексы диенов- 2,5 с повышением температуры уменьшаются, а диенов-1,5 - увеличиваются).

\section{ЛИТЕРА Т У Р А}

1. Петров А. А., Генусов М. Л. Присоединение аллильных хлоридов к алкенам. - ЖОХ, 1963, т. 33, с. $2859-2863$.

2. Пехк Т., Р анг Х., Чернышев В., Эрм А., Л ээт с К. Применение спектроскопии ЯМР ${ }^{13} \mathrm{C}$ для структурного анализа продуктов реакции теломеризации. - Изв. АН ЭССР. Хим., 1978, т. 27, № 3, с. 184-188.

\section{Институт химии \\ Академии наук Эстонской ССР}

Поступила в редакцию $6 / \mathrm{X} 1981$ 